\title{
GAYA KEPIMPINAN SEORANG PEMILIK BUTIK TERHADAP PENGAMBILAN KEPUTUSAN DEMI MEMOTIVASI KARYAWAN Studi Kasus pada MODES HARTINI di Jembatan Merah Plaza (JMP)
}

\section{PROPOSAL PENELITIAN}

Diajukan Sebagai Salah Satu Syarat Untuk Mengikuti Capaian Pembelajaran 2

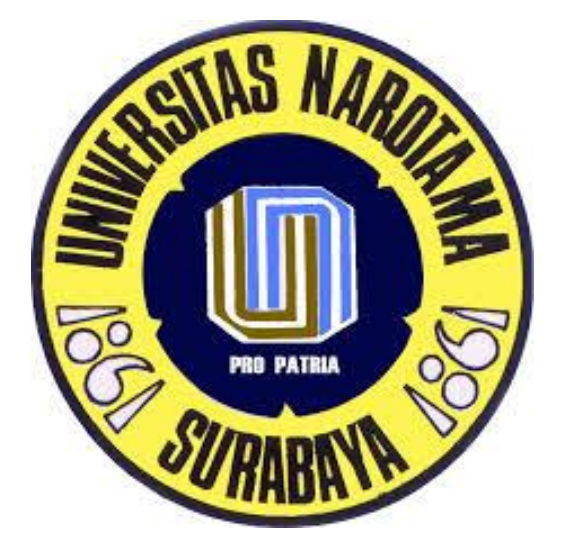

Disusun Oleh

$\begin{array}{ll}\text { Junita Ari Angraini } & 01214228 \\ \text { Lufita Widiana } & 01215008\end{array}$

PROGRAM STUDI MANAJEMEN-FAKULTAS EKONOMI DAN BISNIS UNIVERSITAS NAROTAMA - SURABAYA 2016 


\section{DAFTAR ISI}

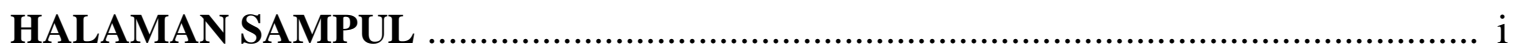

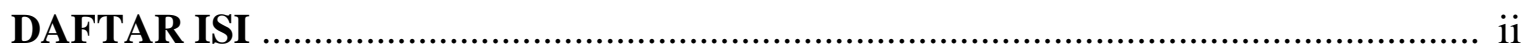
iii

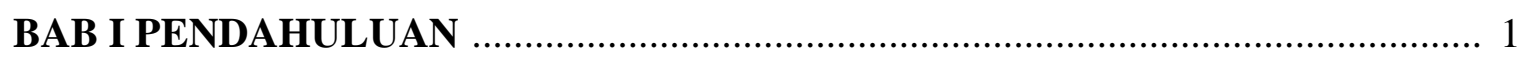

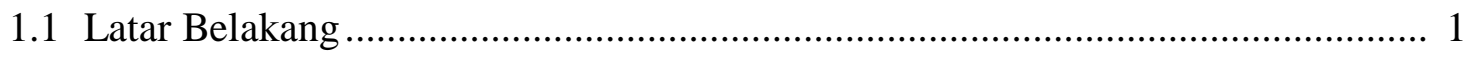

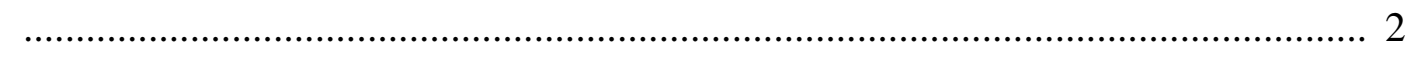

1.2 Perumusan Masalah ........................................................................... 3

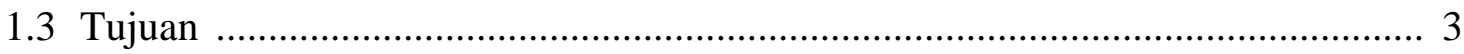

1.4 Manfaat Penelitian ..................................................................................... 3

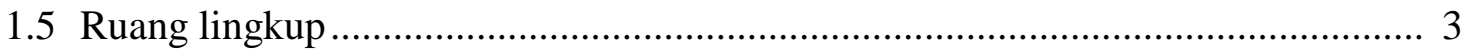

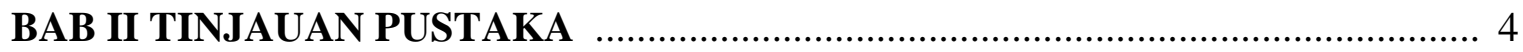

2.1 Hasil penelitian sebelumnya …………………........................................... 4

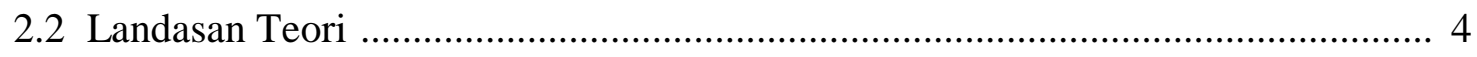

2.2.1 Pengertian gaya kepimpinan ........................................................... 4

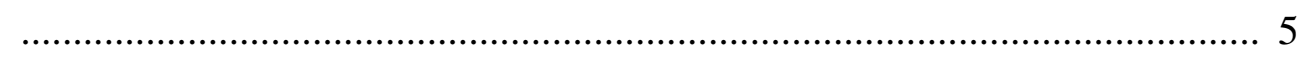

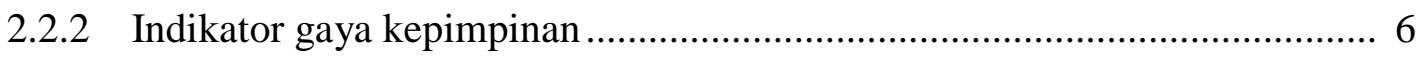

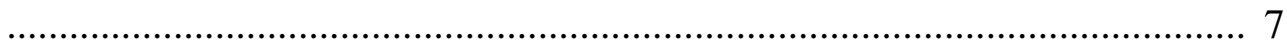

2.2.3 Macam-macam gaya kepimpinan .......................................................... 7

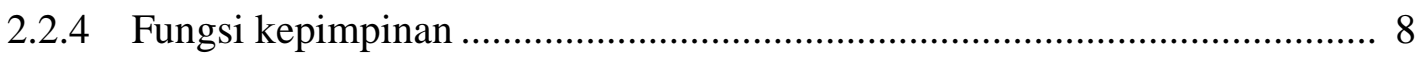

2.2.5 Pengertian kinerja .......................................................................... 9

2.2.6 Faktor-faktor yang mempengaruhi kinerja .................................................. 10

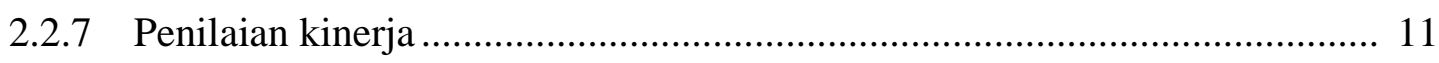

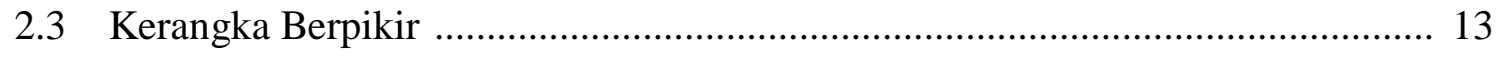

2.3.1 Hubungan antara kinerja dengan kepimpinan ............................................. 12 


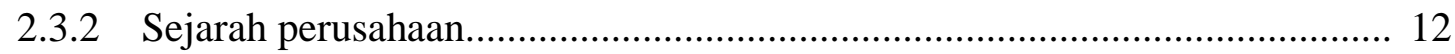

BAB III METODE PENELITIAN ............................................................. 15

3.1 Metode Penelitian ........................................................................................... 15

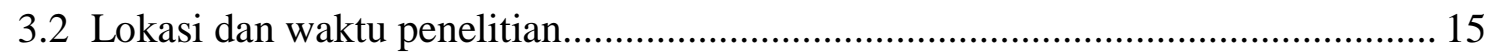

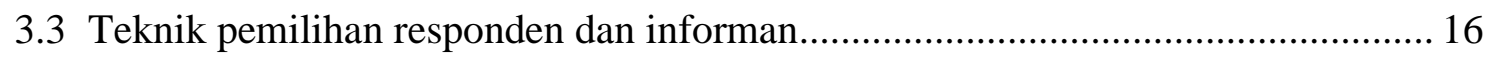

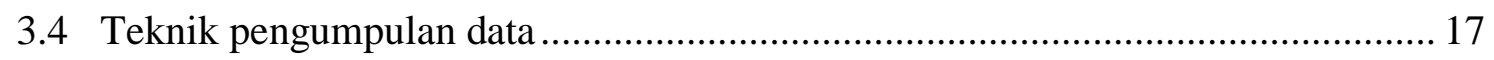

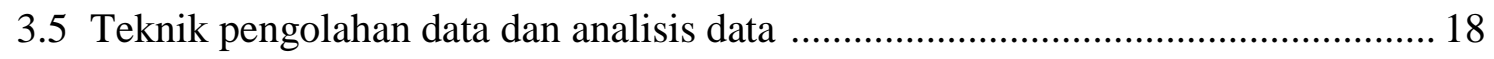

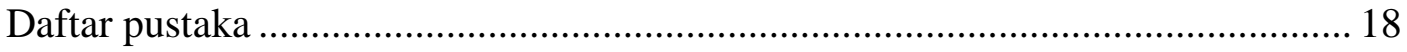

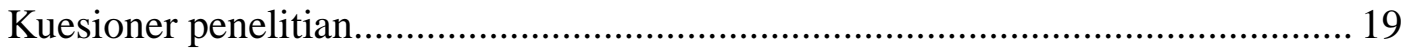

22 


\section{BAB 1}

\section{PENDAHULUAN}

\subsection{LATAR BELAKANG MASALAH}

Pemimpin disebuah usaha merupakan salah satu penentun keberhasilan suatu usaha yang didirikannya. Keberhasilan seorang pemimpin sangat berpengaruh bagi kemajuan dan perkembangan usaha yang dipimpinnya. pemimpinan merupakan seorang yang mengarahkan suatu aktivitas didalam perusahaan yang dipimpinnya. Dan mempunyai tanggung jawab yang besar atas bawahan dan sumber daya organisasi lainnya untuk mencapai tujuan bersama. Seorang pemimpin juga harus mampu dan berani mengambil keputusan terhadap masalah-masalah yang dihadapi usaha yang dipimpinnya.pemimpin suatu perusahaan didalam menjalankan tugasnya haruslah memahami arti dan sasaran yang hendak dicapai agar dapat memajukan perusahaan yang dipimpinnya dan juga seorang pemimpin dituntut agar selalu menjalankan tugas ataupun kewajiban dengan baik.

Seorang pemimpin harus bisa harus bisa mampu memperhatikan dan mengawasi para pegawainya agar dapat bekerja dengan displin tanpa harus melakukan sikap sewenangwenangnya kepada para pegawainya. Pemimpin yang bersifat wenang-wenangnya akan memberikan pengaruh negatif kinerja para pegawainya. Bahkan stress dan frutasi kepada pegawainya sehingga akan membuat tujuan usaha yang dikelolanya menjadi terhambat.

Seorang pemimpin juga harus mengenali sifat-sifat para pegawainya dan dia harus bisa memotivasi para pegawainya agar giat bekerja didalam usaha yang dipimpinnya. Selain itu pemimpin juga harus mempunyai insiatif, wawasan luas dan mempunyai sifat kepimpinan misalnya dalam memberikan bimbingan pengarahan dan pengawasan memperoleh saran memudahkan pegawai baru untuk beradaptasi dilingkungan kerjanya, menanamkan rasa displin kepada para pegawai.bakat tersebut tidak saja berguna didalam melaksanakan pekerjaan dibidangnya tetapi juga akan meningkatkan efisiensi tugas kepimpinannya. 
Seorang pemimpin harus bisa menjalankan fungsi menejemennya seperti planning (perencanaan), organizing(mengorganisasian), actuating(menggerakkan/memimpin) dan controlling(pengawasan). Apabila fungsi menejemen dijalankan dengan baik, maka tujuan perusahaan itu akan tercapai.

Dalam meningkat displin kerja pegawai pimpinan harus bisa memberi contoh semangat kerja dan moral yang tinggi agar pegawai dapat melaksanakan tugas-tugas dan bertanggungjawab dalam pekerjaaanya.displin kerja merupakan sikap dan perilaku untuk menaati segala peraturan dalam pekerjaannya dan kesadaran diri untuk menyesuaikan peraturan pekerjaanya. Pegawai yang memiliki semangat kerja yang tinggi adalah mereka yang displin dalam kerja. Sebaliknya apabila semangat kerja turun, akan mengakibatkan tingkat kedisplinan menjadi turun, menyebabkan kebiasaan-kebiasaan yang tidak baik seperti datang terlambat, tidak hadir maupun bersikap tidak sopan terhadap pimpinan atau pegawai lain. Apabila itu terjadi akan mengakibatkan pekerjaan menjadi terbengkalai dan penurunan kinerja usaha.

Dampak lain dari rendahnya disiplinan yaitu : visi dan misi perusahaan kurang tercapai ,mutu atau kualitas pegawai menjadi turun, korupsi dan manipulasi waktu karna tidak mampu menyelesaikan pekerjaan dengan tepat waktu dan pada akhirnya menyebabkan tujuan usaha tersebut tidak akan tercapai sesuai rencana.

Dari latar belakang penjelasan diatas tentang kepimpinan saya tertarik untuk meneliti pengaruh gaya pimpinan seorang stroe meneger terhadap pengambilan keputusan dalam memotivasi karyawan di GAYA KEPIMPINAN SEORANG PEMILIK BUTIK TERHADAP PENGAMBILAN KEPUTUSAN DEMI MEMOTIVASI KARYAWAN Studi Kasus pada MODES HARTINI di Jembatan Merah Plaza (JMP) 


\subsection{PERUMUSAN MASALAH}

Bagaimana pengaruh gaya kepemimpinan seorang pemilik butik terhadap pengambilan keputusan dalam memotivasi karyawan di MODES HARTINI di Jembatan Merah Plaza?

\subsection{TUJUAN PENELITIAN}

Adapun yang menjadi tujuan kami meneliti memberikan informasi tentang pengaruh untuk peranan pemimpin terhadap pengambilan keputusan dalam memotivasi karyawan di MODES HARTINI di Jembatan Merah Plaza.

\subsection{MANFAAT PENELITIAN}

1. Manfaat teoritis

Menambah wawasan dan pengetahuan kami dibidang menejemen khususnya tentang peranan pimpinan dan displin kerja sehingga kami dapat membandingkan antara praktek dan teori-teori yang dipelajari.

2. Manfaat praktis

Sebagai bahan masukan untuk menambah pengetahuan dan wawasan serta bermanfaat sebagai bahan referensi serta bahan pertimbagan bagi pimpinan untuk dapat lebih memperhatikan terhadap pengambilan keputusan karena dapat mempengaruhi semangat kerja karyawan 


\section{BAB II TINJAUAN PUSTAKA}

Pengertian pemimpin menurut Suradinata (1997:11) adalah orang yang memimpin kelompok dua orang atau lebih, baik organisasi maupun keluarga. Sedangkan kepemimpinan adalah kemampuan seorang pemimpin untuk mengendalikan, memimpin, mempengaruhi fikiran, perasaan atau tingkah laku orang lain untuk mencapai tujuan yang telah ditentukan sebelumnya.

Menurut Winardi (1990:32) bahwa pemimpin terdiri dari pemimpin formal (formal leader) dan pemimpin informal (informal leader). Pemimpin formal adalah seorang (pria atau wanita) yang oleh organisasi tertentu (swasta atau pemerintah) ditunjuk (berdasarkan surat-surat keputusan pengangkatan dari organisasi yang bersangkutan) untuk memangku sesuatu jabatan dalam struktur organisasi yang ada dengan segala hak dan kewajiban yang berkaitan dengannya untuk mencapai sasaran-sasaran organisasi tersebut yang ditetapkan sejak semula. Sedangkan kepemimpinan adalah merupakan suatu kemampuan yang melekat pada diri seorang yang memimpin yang tergantung dari macam-macam faktor, baik faktor intern maupun faktor ekstern.

Siagian (1986:12) berpendapat bahwa kepemimpinan adalah keterampilan dan kemampuan seseorang mempengaruhi perilaku orang lain, baik yang kedudukannya lebih tinggi maupun lebih lebih rendah daripada nya dalam berfikir dan bertindak agar perilaku yang semula mungkin individualistik dan egosentrik berubah menjadi perilaku organisasional.

\section{Teori Kepemimpinan}

Tiga teori yang menjelaskan munculnya pemimpin adalah sebagai berikut (Kartono, 1998:29) :

- Teori Genetis menyatakan sebagai berikut : 1) Pemimpin itu tidak dibuat, akan tetapi lahir jadi pemimpin oleh bakatbakat alami yang luar biasa sejak lahirnya. 2) Dia ditakdirkan lahir menjadi pemimpin dalam situasi dan kondisi yang bagaimanapun juga, yang khusus. 3) Secara filsafat, teori tersebut menganut pandangan deterministis. 
- Teori Sosial (lawan Teori Genetis) menyatakan sebagai berikut : 1) Pemimpin itu harus disiapkan, dididik, dan dibentuk, tidak terlahirkan begitu saja. 2) Setiap orang bisa menjadi pemimpin melalui usaha penyiapan dan pendidikan serta didorong oleh kemauan sendiri.

- Teori Ekologis atau Sintetis (muncul sebagai reaksi dari kedua teori tersebut lebih dahulu), menyatakan sebagai berikut : Seseorang akan sukses menjadi pemimpin bila sejak lahirnya dia telah memiliki bakat-bakat kepemimpinan, dan bakat-bakat ini sempat dikembangkan melalui pengalaman dan usaha pendidikan; juga sesuai dengan tuntutan lingkungan/ekologisnya.

\section{Kelebihan Pemimpin}

Menurut Stogdill dalam Lee (1989), menyatakan bahwa pemimpin itu harus memiliki beberapa kelebihan,yaitu :

- Kapasitas: kecerdasan, kewaspadaan, kemampuan berbicara atau verbal facility, keaslian, kemampuan menilai.

- Prestasi (Achievement) : gelar kesarjanaan, ilmu pengetahuan, perolehan dalam olah raga, dan atletik, dan sebagainya.

- Tanggung Jawab : mandiri, berinisiatif, tekun, ulet, percaya diri, agresif, dan punya hasrat untuk unggul.

- Partisipasi : aktif, memiliki sosiabilitas tinggi, mampu bergaul, kooperatif atau suka bekerjasama, mudah menyesuaikan diri, punya rasa humor.

- Status : meliputi kedudukan sosial ekonomi yang cukup tinggi, populer, tenar.

Menurut Ishak Arep dan Tanjung (2003:93) bahwa kepemimpinan (leadership) adalah kemampuan seseorang untuk menguasai atau mempengaruhi orang lain atau masyarakat yang berbeda-beda manuju pencapaian tertentu. Jadi kepemimpinan atau leadership ini merupakan sifat-sifat yang harus dimiliki oleh seorang pemimpin (leader), yang dalam penerapannya mengandung konsekuensi terhadap diri dalam penerapannya mengandung konsekuensi terhadap diri si pemimpin, antara lain sebagai berikut : 
- Harus berani mengambil keputusan sendiri secara tegas dan tepat (decision making)

- Harus berani menerima resiko sendiri

- Harus berani menerima tanggung jawab sendiri (The Principle of Absolutenes of Responsibility).

\section{Gaya Kepemimpinan}

Selanjutnya Ishak Arep dan Tanjung (2003:23) menyatakan bahwa dalam mencapai tujuan sebagaimana telah dikemukakan diatas, yakni untuk dapat menguasai atau mempengaruhi serta memotivasi orang lain, maka dalam penerapan Manajemen Sumber Daya Manusia lazimnya digunakan 4 (empat) macam gaya kepemimpinan, yaitu :

Democratic Leadership adalah suatau gaya kepemimpinan yang menitikberatkan kepada kemampuan untuk menciptakan moral dan kemampuan untuk menciptakan kepercayaan

Dictatorial atau Autocratic Leadership, yakni suatu gaya leadership yang menityikberatkan kepada kesanggupan untuk memaksakan keinginannya yang mampu mengumpulkan pengikutpengikutnya untuk kepentingan pribadinya dan/atau golongannya dengan kesediaan untuk menerima segala resiko apapun.

Paternalistic Leadership, yakni bentuk antara gaya pertama (democratic) dan kedua (dictatorial) diatas. Yang pada dasarnya kehendak pemimpin juga harus berlaku, namun dengan jalan atau melalui unsur-unsur demokratis. Sistem dapat diibaratkan diktator yang berselimutkan demokratis.

Free Rein Leadership, yakni salah satu gaya kepemimpinan yang 100\% menyerahkan sepenuhnya seluruh kebijakan pengoperasian Manajemen Sumber Daya Manusia kepada bawahannya dengan hanya berpegang kepeda ketentuan-ketentuan pokok yang ditetapkan oleh atasan mereka. Pimpinan disini hanya sekedar mengawasi dari atas dan menerima laporan kebijaksanaan pengoperasian yang telah dilaksanakan oleh bawahannya. Gaya kepemimpinan ini terutama diterapkan oleh Pemerintah Republik Indonesia. 


\section{Tipe Kepemimpinan}

Tipe kepemimpinan bermacam-macam, misalnya tipe kharismatis, paternalistis, militeristis, otokratis, laissez faire, populistis, administratif, dan demokratis. Tipe pemimpin yang dikemukakan oleh W.J. Reddin dalamWhat Kind of Manager yang disunting oleh Wajosumidjo (Dept. P \& K, Pusat Pendidikan dan Latihan Pegawai, 1982), yaitu:

- Berorientasikan tugas (task orientation)

- Berorientasikan hubungan kerja (relationship orientation)

- Berorientasikan hasil yang efektif (effective orientation)

Berdasarkan ketiga orientasi tipe pemimpin tersebut maka terdapat delapan tipe kepemimpinan, yaitu :

- Tipe Deserter (Pembelot) Sifatnya : bermoral rendah, tidak memiliki rasa keterlibatan, tanpa pengabdian, tanpa loyalitas dan kekuatan, sukar diramalkan.

- Tipe Birokrat Sifatnya : correct, kaku, patuh pada peraturan dan norma-norma; ia adalah manusia organisasi yang tepat, cermat, berdisiplin, dan keras.

- Tipe Misionaris (Missionary) Sifatnya : terbuka, penolong, lembut hati, ramah tamah.

- Tipe Developer (Pembangun) Sifatnya : kreatif, dinamis, inovatif, memberikan/melimpahkan wewenang dengan baik, menaruh kepercayaan pada bawahan.

- Tipe Otokrat Sifatnya : keras, diktatoris, mau menang sendiri, keras kepala, sombong. Bandel.

- Benevolent Autocrat (otokrat yang bijak) Sifatnya : lancar, tertib, ahli dalam mengorganisir, besar rasa keterlibatan diri. 
- Tipe Compromiser (kompromis) Sifatnya : plintat plintut, selalu mengikuti angin tanpa pendirian, tidak mempunyai keputusan, berpandangan pendek dan sempit.

- Tipe Eksekutif Sifatnya : bermutu tinggi, dapat memberikan motivasi yang baik, berpandangan jauh, tekun.

\section{Definisi Pengambilan keputusan}

Keputusan adalah hasil pemecahan masalah yang dihadapinya dengan tegas. Hal itu berkaitan dengan jawaban atas pertanyaan-pertanyaan mengenai 'apa yang harus dilakukan' dan seterusnya mengenai unsur-unsur perencanaan. Dapat juga dikatakan bahwa keputusan itu sesungguhnya merupakan hasil proses pemikiran yang berupa pemilihan satu diantara beberapa alternatif yang dapat digunakan untuk memecahkan masalah yang dihadapinya.

Keputusan itu sendiri merupakan unsur kegiatan yang sangat vital. Jiwa kepemimpinan seseorang itu dapat diketahui dari kemampuan mengatasi masalah dan mengambil keputusan yang tepat. Keputusan yang tepat adalah keputusan yang berbobot dan dapat diterima bawahan. Ini biasanya merupakan keseimbangan antara disiplin yang harus ditegakkan dan sikap manusiawi terhadap bawahan. Keputusan yang demikian ini juga dinamakan keputusan yang mendasarkan diri pada human relations.

Setelah pengertian keputusan disampaikan, kiranya perlu pula diikuti dengan pengertian tentang “pengambilan keputusan”. Ada beberapa definisi tentang pengambilan keputusan, dalam hal ini arti pengambilan keputusan sama dengan pembuatan keputusan, misalnya Terry, definisi pengambilan keputusan adalah pemilihan alternatif perilaku dari dua alternatif atau lebih ( tindakan pimpinan untuk menyelesaikan masalah yang dihadapi dalam organisasi yang dipimpinnya dengan melalui pemilihan satu diantara alternatif-alternatif yang dimungkinkan).

Menurut Siagian pengambilan keputusan adalah suatu pendekatan terhadap hakikat suatu masalah, pengumpulan fakta-fakta dan data, penentuan yang matang dari alternatif yang dihadapi dan pengambilan tindakan yang menurut perhitungan merupakan tindakan yang paling tepat.

Dari kedua pengertian diatas maka dapat ditarik kesimpulan bahwa keputusan itu diambil dengan sengaja, tidak secara kebetulan, dan tidak boleh sembarangan. Masalahnya telebih dahulu 
harus diketahui dan dirumuskan dengan jelas, sedangkan pemecahannya harus didasarkan pemilihan alternatif terbaik dari alternatif yang ada.

\section{Tujuan Pengambilan Keputusan}

Kegiatan-kegiatan yang dilakukan dalam organisasi itu dimaksudkan untuk mencapai tujuan organisasinya yang dimana diinginkan semua kegiatan itu dapat berjalan lancer dan tujuan dapat dicapai dengan mudah dan efisien. Namun, kerap kali terjadi hambatan-hambatan dalam melaksanakan kegiatan. Ini merupakan masalah yang hatus dipecahkan oleh pimpinan organisasi. Pengambilan keputusan dimaksudkan untuk memecahkan masalah tersebut.

\section{Dasar Pengambilan Keputusan}

\section{Pengambilan Keputusan Berdasarkan Intuisi}

Keputusan yang diambil berdasarkan intuisi atau perasaan lebih bersifat subjektif yaitu mudah terkena sugesti, pengaruh luar, dan faktor kejiwaan lain. Sifat subjektif dari keputusuan intuitif ini terdapat beberapa keuntungan, yaitu :

- Pengambilan keputusan oleh satu pihak sehingga mudah untuk memutuskan.

- Keputusan intuitif lebih tepat untuk masalah-masalah yang bersifat kemanusiaan.

Pengambilan keputusan yang berdasarkan intuisi membutuhkan waktu yang singkat Untuk masalah-masalah yang dampaknya terbatas, pada umumnya pengambilan keputusan yang bersifat intuitif akan memberikan kepuasan. Akan tetapi, pengambilan keputusan ini sulit diukur kebenarannya karena kesulitan mencari pembandingnya dengan kata lain hal ini diakibatkan pengambilan keputusan intuitif hanya diambil oleh satu pihak saja sehingga hal-hal yang lain sering diabaikan.

2. Pengambilan Keputusan Rasional 
Keputusan yang bersifat rasional berkaitan dengan daya guna. Masalah - masalah yang dihadapi merupakan masalah yang memerlukan pemecahan rasional. Keputusan yang dibuat berdasarkan pertimbangan rasional lebih bersifat objektif. Dalam masyarakat, keputusan yang rasional dapat diukur apabila kepuasan optimal masyarakat dapat terlaksana dalam batas-batas nilai masyarakat yang di akui saat itu.

\section{Pengambilan Keputusan Berdasarkan Fakta}

Ada yang berpendapat bahwa sebaiknya pengambilan keputusan didukung oleh sejumlah fakta yang memadai. Sebenarnya istilah fakta perlu dikaitkan dengan istilah data dan informasi. Kumpulan fakta yang telah dikelompokkan secara sistematis dinamakan data. Sedangkan informasi adalah hasil pengolahan dari data. Dengan demikinan, data harus diolah lebih dulu menjadi informasi yang kemudian dijadikan dasar pengambilan keputusan.Keputusan yang berdasarkan sejumlah fakta, data atau informasi yang cukup itu memang merupakan keputusan yang baik dan solid, namun untuk mendapatkan informasi yang cukup itu sangat sulit.

\section{Pengambilan Keputusan Berdasarkan Pengalaman}

Sering kali terjadi bahwa sebelum mengambil keputusan, pimpinan mengingat-ingat apakah kasus seperti ini sebelumnya pernah terjadi. Pengingatan semacam itu biasanya ditelusuri melalui arsip-arsip penhambilan keputusan yang berupa dokumentasi pengalaman-pengalaman masa lampau. Jika ternyata permasalahan tersebut pernah terjadi sebelumnya, maka pimpinan tinggal melihat apakah permasalahan tersebut sama atau tidak dengan situasi dan kondisi saat ini. Jika masih sama kemudian dapat menerapkan cara yang sebelumnya itu untuk mengatasi masalah yang timbul.

Dalam hal tersebut, pengalaman memang dapat dijadikan pedoman dalam menyelesaikan masalah. Keputusan yang berdasarkan pengalaman sangat bermanfaat bagi pengetahuan praktis. Pengalaman dan kemampuan untuk memperkirakan apa yang menjadi latar belakang masalah dan bagaimana arah penyelesaiannya sangat membantu dalam memudahkan pemecaha masalah.

\section{Pengambilan Keputusan Berdasarkan Wewenang}


Banyak sekali keputusan yang diambil karena wewenang (authority) yang dimiliki. Setiap orang yang menjadi pimpinan organisasi mempunyai tugas dan wewenang untuk mengambil keputusan dalam rangka menjalankan kegiatan demi tercapainya tujuan organisasi yang efektif dan efisien.

Keputusan yang berdasarkan wewenang memiliki beberapa keuntungan. Keuntungankeuntungan tersebut antara lain : banyak diterimanya oleh bawahan, memiliki otentisitas (otentik), dan juga karena didasari wewenang yang resmi maka akan lebih permanent sifatnya.

Keputusan yang berdasarkan pada wewenang semata maka akan menimbulkan sifat rutin dan mengasosiasikan dengan praktik dictatorial. Keputusan berdasarkan wewenang kadangkala oleh pembuat keputusan sering melewati permasahan yang seharusnya dipecahkan justru menjadi kabur atau kurang jelas.

Faktor-faktor yang perlu diperhatikan dalam Pengambilan Keputusan

Faktor-faktor yang perlu diperhatikan dalam pengambilan keputusan menurut Terry,yaitu :

a) Hal-hal yang berwujud maupun yang tidak berwujud, yang emosional maupun yang rasional perlu diperhitungkan dalam pengambilan keputusan.

b) Setiap keputusan harus dapat dijadikan bahan untuk mencapai tujuan organisasi.

c) Setiap keputusan jangan berorientasi pada kepentingan pribadi, tetapi harus lebih mementingkan kepentingan organisasi.

d) Jarang sekali pilihan yang memuaskan, oleh karena itu buatlah altenatif-alternatif tandingan.

e) Pengambilan keputusan merupakan tindakan mental dari tindakan ini harus diubah menjadi tindakan fisik.

f) Pengambilan keputusan yang efektif membutuhkan waktu yang cukup lama.

g) Diperlukan pengambilan keputusan yang praktis untuk mendapatkan hasil yang lebih baik. 
h) Setiap keputusan hendaknya dilembagakan agar diketahui keputusan itu benar.

i) Setiap keputusan merupakan tindakan permulaan dari serangkaian kegiatan mata rantai berikutnya.

Keputusan Individual dan Kelompok

Pengambilan keputusan dapat dilakukan secara individual atau kelompok, tergantung bagaimana sifat dan corak permasalahannya. Keputusan individual dibuat oleh seorang pemimpin sendirian, sedangkan keputusan kelompok dibuat sekelompok orang. Keputusan kelompok dibedakan dalam :

a) Sekelompok pimpinan

b) Sekelompok orang-orang bersama pimpinannya.

c) Sekelompok orang yang mempunyai kedudukan sama dan keputusan kelompok

Keputusan yang dibuat oleh seseorang

Kebaikannya antara lain :

1. Keputusannya cepat ditentukan atau diambil, karena tidak usah menunggu persetujuan dari rekan lainnya.

2. Tidak akan terjadi pertentangan pendapat

3. Kalau pimpinan ya ng mengambil keputusan itu mempunyai kemampuan yang tinggi dan berpengalaman yang luas dalam bidang yang akan diputuskan, keputusannya besar kemungkinan tepat.

Kelemahannya antara lain :

1. Bagaimana kepandaian dan kemampuan pimpinan tetapi pasti memiliki keterbatasan.

2. Keputusan yang terlalu cepat diambil dan tidak meminta pendapat orang lain seringkali kurang tepat. 
3. Jika terjadi kesalahan pengambilan keputusan merupakan beban berat bagi pimpinan seorang diri.

Keputusan yang dibuat oleh Sekelompok Orang

Kelebihannya antara lain :

1. Hasil pemikiran beberapa orang akan saling melengkapi

2. Pertimbangannya akan lebih matang

3. Jika ada kesalahan pada pengambilan keputusan tersebut, beban ditanggung secara bersama.

Kelemahannya antara lain :

1. Ada kemingkinan terjadi perbedaan pendapat

2. Biasanya memakan waktu lama dan berlarut-larut karena terjadi perdebatan-perdebatan

3. Rasa tanggung jawab masing-masing berkurang, dan ada kemungkinan saling melemparkan tanggung jawab jika terjadi kesalahan.

Mengenai pembuatan keputusan individual dan kelompok Siagian menyatakan bahwa ada tiga kekuatan yang selalu mempengaruhui suatu keputusan yang dibuat. Tiga kekuatan itu :

1. Dinamika individu di dalam organisasi

Pengaruh individu dalam organisasi sangat terasa terutama dalam hal ini adalah

pemimpinnya. Seorang pemimpin yang mempunyai kepribadian yang kuat, pendidikan yang tinggi, pengalaman ynag banyak akan memberi kesan dan pengaruh yang besar terhadap bawahannya

2. Dinamika kelompok orang-orang di dalam organisasi 
Dinamika kelompok mempunyai pengaruh besar, oleh karena itu pemimpin hendaknya mengusahakan agar kelompok lebih cepat menjadi dewasa.

\section{Dinamika lingkungan organisasi}

Pengaruh lingkungan juga memegang peranan yang cukup penting untuk diperhatikan. Antara organisasi dan lingkungan itu saling mempemgaruhi.

\section{Proses Pengambilan Keputusan}

Setiap keputusan yang diambil itu merupakan perwujudan kebijakan yang telah digariskan. Oleh karena itu, analisis proses pengambilan keputusan pada hakikatnya sama saja dengan analisis proses kebijakan. Proses pengambilan keputusan meliputi :

Identifikasi masalah

Dalam hal ini pemimpin diharapkan mampu mengindentifikasikan masalah yang ada di dalam suatu organisasi.

Pengumpulan dan penganalisis data

Pemimpin diharapkan dapat mengumpulkan dan menganalisis data yang dapat membantu memecahkan masalah yang ada.

Pembuatan alternatif-alternatif kebijakan

Setelah masalah dirinci dengan tepat dan tersusun baik, maka perlu dipikirkan cara-cara pemecahannya. Cara pemecahan ini hendaknya selalu diusahakan adanya alternatif-alternatif beserta konsekuensinya, baik positif maupun negatif. Oleh sebab itu, seorang pimpinan harus dapat mengadakan perkiraan sebaik-baiknya. Untuk mengadakan perkiraan dibutuhkan adanya informasi yang secukupnya dan metode perkiraan yang baik. Perkiraan itu terdiri dari berbagai macam pengertian: 
- Perkiraan dalam arti Proyeksi Perkiraan yang mengarah pada kecenderungan dari data yang telah terkumpul dan tersusun secara kronologis.

- Perkiraan dalam arti prediksi Perkiraan yang dilakukan dengan menggunakan analisis sebab akibat.

- Perkiraan dalam arti konjeksi Perkiraan yang didasarkan pada kekuatan intuisi (perasaan). Intuisi disini sifatnya subjektif, artinya tergantung dari kemampuan seseorang untuk mengolah perasaan.

Pemilihan salah satu alternatif terbaik

Pemilihan satu alternatif yang dianggap paling tepat untuk memecahkan masalah tertentu dilakukan atas dasar pertimbangan yang matang atau rekomendasi. Dalam pemilihan satu alternatif dibutuhkan waktu yang lama karena hal ini menentukan alternative yang dipakai akan berhasil atau sebaliknya.

\section{Pelaksanaan keputusan}

Dalam pelaksanaan keputusan berarti seorang pemimpin harus mampu menerima dampak yang positif atau negatif. Ketika menerima dampak yang negatif, pemimpin harus juga mempunyai alternatif yang lain.

Pemantauan dan pengevaluasian hasil pelaksanaan

Setelah keputusan dijalankan seharusnya pimpinan dapat mengukur dampak dari keputusan yang telah dibuat 


\section{BAB III}

\section{METODOLOGI PENELITIAN}

\subsection{Metode Penelitian}

Menurut Bogdan dan Taylor (1975) yang dikutip oleh Moleong (2007:4) mengemukakan bahwa metodologi kualitatif sebagai prosedur penelitian yang menghasilkan data deskriptif berupa katakata tertulis atau lisan dari orang-orang dan perilaku yang dapat diamati.

Mengacu pada pendapat craswell (1994), maka pemilihan atas metode penelitian kualitatif :

- Pandangan peneliti ini mencerminkan "kemantapan" peneliti terhadap ansumsi ontologis, epistemologis, aksiologis dan metodologis dari salah satu pendekatan. Jika peneliti cenderung pada kedalaman pemahaman dari suatu fenomena, maka ia mesti memilih metode kualitatif

- Latihan dan pengalaman peneliti, latihan-latihan dan pengalaman penggunaan dari suatu metode penelitian tertentu, tentu saja sangat membantu dalam aplikasi metode tersebut,para peneliti yang memiliki banyak pengalaman dalam penulisan essay, terbiasa membaca jurnal penelitian kualitatif, mengusai software computer untuk analisis kualitatif

- Bagi peneliti yang bersedia mengambil resiko yang melekat dalam prosedur yang racun dan pelaksanaan penelitian yang memerlukan waktu lama, maka ia cocok untuk memilih metode kualitatif.

- Sifat masalah peneliti yang menggunakan metode kualitatif pada umumnya harus menggali terlebih dahulu masalah penelitian, karena sedikitnya informasi tentang masalah tersebut. Variable tidak banyak diketahui, oleh karena itu penelitian harus 
memusatkan perhatian terhadap konteks agar dapat memahami fenomena yang sedang diteliti.

Disamping alasan diatas dalam penelitian ini digunakan pendekatan kualitatif disebabkan beberapa hal yang cukup penting antara lain : pertama, karena latar belakang penelitian tidak bersifat homogen, kedua karena penelitian ini ingin mengungkap data dengan apa adanya sesuai hasil temuan dilapangan tentang kepemimpinan stroe manager di MODES HARTINI di Jembatan Merah Plaza

\section{Kehadiran peneliti- metode penelitian}

Memperoleh data-data yang valid dan obyektif terhadap apa yang diteliti kehadiran peneliti di lapangan sangat diperlukan. Kehadiran peneliti di dalam lapangan berguna untuk mengamati kejadian atau fenomena dalam lapangan yang akan diteliti, maka dengan riset lapangan dalam penelitian ini dapat menemukan dan mengumpulkan data untuk menentukan hasil penelitian, jadi dalam penelitian instrument penelitian adalah penelitian sendiri sekaligus sebagai pengumpulan data, sedangkan instrument yang lain adalah pendukung atau instrument pelengkap.

\section{Prosedur pengumpulan data}

Penelitian ini menggunakan pengumpulan data dengan kehadiran peneliti untuk terjun langsung dilapangan untuk mengumpulkan data, melalui observasi, maupun wawancara dan interview secara lebih rinci teknik yang dilakukan dalam pengumpulan data adalah :

1. Metode observasi (pengamatan)

Pada dasarnya metode observasi digunakan untuk melihat dan mengamati perubahan fenomena-fenomena social yang tumbuh dan berkembang yang kemudian dapat 
dilakukan perubahan atas penilaian tersebut, bagi pelaksana observasi untuk melihat obyek moment tertentu, sehingga mampu memisahkan antara yang diperlukan dengan yang tidak di perlukan (Margono, 2007:159)

2. Metode wawancara

Wawancara adalah pertemuan dua orang untuk bertukar informasi dan ide melalui Tanya jawab sehingga dapat dikonstruksikan makna dalam suatu topic tertentu dan dengan wawancara, peneliti akan mengetahui hal-hal yang lebih mendalam tentang partisipan dalam menginterprestasikan situasi dan fenomena yang terjadi yang tidak mungkin bisa ditemukan melalui observasi.

\section{PEMBAHASAN}

Pemimpin disebuah usaha merupakan salah satu penentun keberhasilan suatu usaha yang didirikannya. Keberhasilan seorang pemimpin sangat berpengaruh bagi kemajuan dan perkembangan usaha yang dipimpinnya. pemimpinan merupakan seorang yang mengarahkan suatu aktivitas didalam perusahaan yang dipimpinnya.

Dari hasil Wawancara tanggal 24 desember 2017 “ Bagaimana peran Ibu Hartini selaku pemilik usaha dan pemimpin usaha di MODES HARTINI di Jembatan Merah Plaza dalam memotivasi karyawan untuk semangat bekerjanya tinggi dan menaati peraturan yang ibu bikin serta mengambil keputusan dalam segala hal di dalam usaha ibu agar tujuan struktur usaha ibu tercapai dan tujuan usaha ibu juga tercapai”? Menurut Ibu Hartini beliau memberikan contohcontoh yang baik dalam prilakunya di tempat usahanya tersebut agar karyawannya mencontoh prilakunya tersebut, dan tidak membeda-bedakan karyawan sehingga karyawan merasa diperlakukan adil sehingga keputusan yang saya buat selalu anggap mereka untuk kebaikan 
bersama. Dan menurut Ibu Hartini juga keberhasilan suatu usaha bisa terjadi jika komponen dalam usaha tersebut selalu semangat dan kompak dalam segala hal yang mereka lakukan dan antara pemilik usaha dan karyawan terjalin komunikasi yang baik.

\section{KESIMPULAN}

Dalam suatu usaha pengambilan keputusan sangatlah penting untuk melakukan aktivitas dalam suatu usaha, keputusan itu tidak boleh diambil secara sembarang pengambilan keputusan harus masalahnya terlebih dahulu harus diketahui dan dirumuskan secara jelas dan penuh musyawarah. Dan pengambilan keputusan yang efektif dapat berpengaruh terhadap peningkatan kualitas usaha yang dalam implementasinya bisa melalui variabel perantara yaitu meningkatkan kinerja, semangat, kreativitas dari karyawan-karyawan yang dipimpinanya.

\section{DAFTAR PUSTAKA}

Arep, Ishak dan Hendri Tanjung. (2003). Manajemen Motivasi. Penerbit PT.Gramedia Widiasarana Indonesia, Jakarta.

Kartono, Kartini. (1998). Pemimpin dan Kepemimpinan : Apakah Pemimpinan Abnormal Itu ? PT Raja Grafindo Persada, Jakarta.

Siagian, S. P. (1982). Administrasi Pembangunan. Gunung Agung, Jakarta.

Suradinata, Ermaya. (1995). Psikologi Kepegawaian dan Peranan Pimpinan Dalam Motivasi Kerja . CV Ramadan, Bandung.

Winardi. (1990). Kepemimpinan Dalam Manajemen. PT. Rineka Cipta, Jakarta

Kasim, Azhar. Teori Pembuatan Keputusan. Jakarta : Lembaga Penerbit FE UI. 1995

Syamsi, Ibnu. Pengambilan Keputusan (Decision Making). Jakarta : Bina Aksara. 1989

www.antaranews.com diakses Senin, 16 November 2009

http://ojan-jan.blogspot.com/ 
Margono S. Drs.2007. Metologi penelitian pendidikan kompenen MKDK PT. Rineka Cipta, Jakarta

Sugiono (2009). Metode penelitian pendekatan kuantitatif, kualitatif dan R\&D Bandung: Alfa Beta

Dr. Arasy Alimudin, SE, MM 